UDC 332; DOI 10.18551/rjoas.2022-01.10

\title{
STRATEGY FOR WOMEN'S EMPOWERMENT AROUND THE MARTAPURA WATERSHED IN THE UTILIZATION OF THE YARD FOR MEDICINE PLANT FAMILY
}

\author{
Rosni Masyhudah*, Budiwati Nina \\ Study Program of Agribusiness, Faculty of Agriculture, University of Lambung Mangkurat, \\ Banjarbaru, Indonesia \\ *E-mail: masyhudah.rosni@ulm.ac.id
}

\begin{abstract}
One of the programs that can be implemented by women managing watersheds (DAS) in an effort to improve family welfare and preserve the environment, especially in the food sector, is the program for planting and utilizing the watershed environment as a place to plant Family Medicinal Plants (TOGA). This program also responds to the decline in people's purchasing power due to increasingly expensive drug prices, so that it indirectly has an impact on the decline in public health status. The general purpose of the research is to see the efforts of empowering women around the Martapura watershed in the use of yard land to plant TOGA by formulating strategies and programs for women's empowerment. To answer these objectives, a SWOT analysis was carried out to determine the strategy and then continued with the Process Hierarchy (AHP) analysis to determine the priority strategy. The total score of internal and external factors is 1.4384 and 0.2465 , respectively. So it can be concluded that the strategy of Empowering Women Around the Martapura Watershed in the use of yard land for TOGA farming is in quadrant I position, a very favorable condition. The priority strategies based on the results of questionnaire data processing using the AHP method are WO2: developing products produced through processing results $(38.52 \%)$, WO1: conducting partnership programs between producers and marketing agencies (27.50\%), SO1: relying on product advantages (11.78\%), SO2: promoting socialization of the use of family medicinal plant cultivation (TOGA) through face-to-face and social media (7.95\%), WT1: establishment of a medicinal plant market by the relevant agencies $(6.64 \%)$, ST1 : re-encouragement of extensions to business actors of family medicinal plants (TOGA) (4.53\%), and ST2: holding seminars/business promotions regarding the benefits of using family medicinal plants (TOGA) $(7.56 \%)$.
\end{abstract}

\section{KEY WORDS}

Empowerment, DAS, TOGA, AHP, SWOT.

The development of civilization in Indonesia is currently growing in the scope of practical culture and ideology, leaving negative impacts on various aspects of life and community structure and has created gender inequality (Kuncoro \& Kadar, 2016).

Efforts to optimize women's empowerment and efforts to awaken poor areas can be pursued, one of which can be done by assisting women to increase the potential of existing women, through the development of productive businesses and diversification of local products in groups. In the process of empowering women, they are invited to first identify what are the real needs of women, both practical needs and strategic needs, and the problems. By knowing their own needs, it is hoped that they will be able to find solutions to their problems. So that women themselves determine the planning, implementation, and evaluation of the specified solution (Saptatiningsih, 2015).

Watershed management efforts are needed to encourage environmental sustainability to be realized, create a balance of ecosystems and ensure sustainability between the benefits of natural resources (SDA) in the watershed for humans. This means that every form of utilization of natural resources is carried out by taking into account and considering aspects of watershed sustainability, it is hoped that future generations will be able to feel the benefits. 
Kodoatie and Sugiyanto (2002) define a watershed as a unitary area/region/water system area that is formed naturally where water is caught (derived from rainfall), and will flow from the area/region/area towards the rivers and streams concerned, also called the River Drainage Area (DPS) or Water Catchment Area (DTA). In English there are several kinds of terms, namely Catchment Area, Watershed. Asdak (2010) defines a watershed (DAS) as a land area that is topographically limited by mountain ridges that accommodate and store rainwater to then channel it to the sea through the main river.

One of the programs that can be implemented by women managing watersheds in an effort to improve family welfare and preserve the environment, especially in the food sector, is the program for planting and utilizing the watershed environment as a place to plant Family Medicinal Plants (TOGA). This program also responds to the decline in people's purchasing power due to increasingly expensive drug prices, so that it indirectly has an impact on the decline in public health status. TOGA is a home-grown plant that has medicinal properties. TOGA can be planted in pots or in the land around the house, and if the land planted is large enough then some of the harvest can be sold and increase family income. As for the use of TOGA, apart from being a medicine, it can also be used to: (1) enhance family nutrition (papaya, cucumber, spinach), (2) cooking spices or herbs (turmeric, kencur, ginger, lemongrass, bay leaf), (3 ) add to the beauty (rose, jasmine, sunflower, hibiscus, tread virgin, cat's whiskers).

One of the most important watersheds for the lives of the people of South Kalimantan, especially the people who live in Banjar Regency and Banjarmasin City, is the Martapura River watershed which is widely used by the surrounding community as a place for aquaculture, transportation, floating markets (Lokbaitan and Siring Banjarmasin), tourism and many more other uses. In addition to being used directly by the river, the watershed has also been used for a long time by people living in the watershed who have businesses in the field of food crop agriculture and horticultural crop farming as a source of irrigation water for the plants they cultivate. As previously mentioned, one of the programs that can be implemented by women in watershed management in an effort to improve family welfare and preserve the environment, especially in the food sector, is a program for planting and utilizing the watershed environment as a place to plant Family Medicinal Plants (TOGA) where women are empowered to take advantage of existing yards. around residential houses located around the Martapura River watershed by planting Family Medicinal Plants (TOGA) by utilizing the potential resources of the watershed as a source of irrigation and organic matter (watershed mud) which is good for the growth of Family Medicinal Plants (TOGA).

According to Hartono, et al. (1985) in Rahayu and Prawiroatmaja (2005), the yard is a plot of land that has certain boundaries, on which there are residential buildings and have functional relationships of economic, biophysical and socio-cultural with the occupants. According to Novitas (2011) in Ashari et al. (2012) also explained that the yard is seen as a land use which is a small-scale additional food production system for and by household members and is a layered canopy ecosystem. According to Widagda et al. (1984) in Affandi (2002) the structure of the yard is the same every year, although there are differences according to seasons. The lowest stratum (under one meter) is dominated by vegetables and spices, lombok, eggplant, and galangal.

The yard has a number of roles in the socio-economic life of the farmer's household. According to Sajogyo (1994) in Ashari et al. (2012), Pekarangan is often called a living barn, a living shop or a living pharmacy. It is called a living barn because at any time basic food needs such as corn, tubers and so on are available in the yard. These materials are stored in the yard alive. It is called a live shop, because in the yard there are vegetables that are useful to meet the consumption needs of the family, where some households have to buy it with cash. Meanwhile, it is called a live pharmacy because in the yard are planted with various medicinal plants which are very useful in curing diseases traditionally.

Medicinal plants are plants or plants that have properties for human health and are used as ingredients to make natural medicines that are relatively safer. The side effects are relatively mild compared to chemical drugs which have high toxicity. Medicinal plants can also be cultivated or developed at a lower cost (Pranata, 2014). 
Based on this background, in our opinion, it is necessary to conduct research on empowering women around the Martapura watershed (DAS) in the use of yard land to plant Family Medicinal Plants (TOGA) as an effort to improve the health and economy of the community with the aim of general research activities to see efforts -Efforts to empower women around the Martapura watershed (DAS) in the use of yard land to plant Family Medicinal Plants (TOGA) by formulating strategies and programs for empowering women around the Martapura watershed (DAS) in using yard land to plant Family Medicinal Plants (TOGA).

\section{METHODS OF RESEARCH}

Research was conducted in Banjar Regency. The determination of the research location was carried out intentionally, with the consideration that the location is an area that has the largest population of residents inhabiting the Martapura Watershed (DAS). This study uses quantitative methods supported by a qualitative data approach to enrich the data and information obtained in order to understand social phenomena that occur in the field. The subjects in this study were respondents and informants. Respondents are people who are chosen to tell about themselves or who experience directly the social phenomenon being studied. Informants are people who can provide information about themselves, others, and the environment. Qualitative and quantitative data processing is carried out through data reduction, namely sorting, focusing, and simplifying the data so that it can be used to answer research objectives. Quantitative data obtained through questionnaires will be processed using Microsoft Excel. To answer the objectives, namely strategies and programs for empowering women around the Martapura watershed (DAS) in the use of yard land to plant Family Medicinal Plants (TOGA) using SWOT analysis and AHP analysis (Analysis Hierarchy Process).

AHP was carried out by taking purposive sampling with the aim of being able to select respondents related to the strategy and empowerment of women around the Martapura watershed (DAS) in the use of yard land to plant Family Medicinal Plants (TOGA). Interviews with key persons using a questionnaire. In the AHP method, the following steps are taken (Marimin, 2004):

Hierarchy Preparation. The problem to be solved is broken down into its elements, namely criteria and alternatives, and then arranged into a hierarchical structure. The diagram that will be made will later present the decisions in the strategy and program for empowering women around the Martapura watershed (DAS) in the use of yard land to plant Family Medicinal Plants (TOGA).

Assessment of criteria and alternatives. Criteria and alternatives were assessed throughpairwise comparisons. According to Saaty (1983) in Marimin (2004) for various issues, a scale of 1 to 9 is the best scale in expressing opinions.

Priority Determination. Each criterion and alternative needs to be compared in pairs (pairwise comparisons). The relative comparison values are then processed to determine the relative ranking of all alternatives. Marimin (2004) states that both qualitative criteria and quantitative criteria can be compared according to predetermined judgments to produce weights and priorities.

Logical Consistency. All elements are grouped logically and accounted for consistently according to a logical criterion. The expected consistency is near perfect in order to produce a decision that is close to valid. Although it is difficult to achieve perfection, the expected consistency ratio is less than or equal to $10 \%$. If the consistency ratio requirements are not met, then the assessment is still random and needs to be improved (Marimin and Maghfiroh, 2010).

\section{RESULTS AND DISCUSSION}

According to Gurel and Merba (2017), SWOT analysis is a method used in strategic planning and strategic management of an organization. Can be used to create organizational 
strategies and competitive strategies. Meanwhile, as quoted by Mondal (2017) according to Wang and Zheng (2015), SWOT analysis usually looks for information about the strengths and weaknesses within the company, as well as opportunities and threats from the company's external environment as a means for decision makers to get the best strategy.

SWOT analysis has four component factors - factors according to Ifediora et al. (2014) in Hashemi et al. (2017) as follows:

- Strengths enable actors to complete the organization's mission;

- Weaknesess are drawback associated with factors within the organization that could hamper the achievement of a successful outcome for the organization;

- Opportunities are related to external components, can help in achieving the goals set for the organization;

- Threats exist when conditions in the external environment jeopardize the advantages and benefits of the organization.

Table 1 - Identification of Internal Factors (IFAS) and External Factors (EFAS) Strategies for Empowering Women around the Martapura Watershed (DAS) in the Utilization of Yard Land for Farming TOGA

\begin{tabular}{|l|l|l|}
\hline IFAS & Code & Internal Factors \\
\hline \multirow{4}{*}{ Strengths } & S1 & TOGA has multifunction \\
\cline { 2 - 3 } & S2 & Seeds are easy to getbe \\
\cline { 2 - 3 } & S3 & Can be planted in a narrow area \\
\cline { 2 - 3 } & S4 & As first aid medicine \\
\cline { 2 - 3 } & S5 & Reduces doctor fees \\
\hline \multirow{5}{*}{ Weakness } & W1 & TOGA price is low \\
\cline { 2 - 3 } & W2 & Lack of orders/demands \\
\cline { 2 - 3 } & W3 & Poorly developed relations \\
\cline { 2 - 3 } & W4 & No post-harvest processing \\
\cline { 2 - 3 } & W5 & Drugs from TOGA are less practical \\
\hline EFAS & Kode & External Factors \\
\hline Oppotunities & O1 & Community needs for needs everyday \\
\cline { 2 - 3 } & O2 & healthy lifestyle \\
\cline { 2 - 3 } & O3 & Opening up the business / work \\
\hline Threats & T1 & presence of generic / chemical \\
\cline { 2 - 3 } & T2 & TOGA Lack of interest \\
\cline { 2 - 3 } & T3 & Lack of government support \\
\hline
\end{tabular}

Calculation of IFAS and EFAS is the process of processing weight anddata rating on each factor. The calculation of the IFAS and EFAS factors can be seen in Tables 2 and 3.

Table 2 - IFAS Calculation of Women's Empowerment Strategy Around the Martapura Watershed (DAS) in the Utilization of Yard Land for TOGA Farming

\begin{tabular}{|c|c|c|c|c|c|}
\hline \multicolumn{6}{|c|}{ INTERNAL FACTORS } \\
\hline No & Code & Strength(S) & Weight & Rating & Score \\
\hline 1 & S1 & TOGA has multifunction & 0.376 & 4 & 1.504 \\
\hline 2 & S2 & Seeds are easy to get & 0,1613 & 3 & 0.484 \\
\hline 3 & S3 & Can be planted in a narrow area & 0.1216 & 2 & 0.2432 \\
\hline 4 & S4 & As a first aid medicine & 0.0632 & 1 & 0.0632 \\
\hline 5 & S5 & Reduce doctor costs & 0.0256 & 1 & 0.0256 \\
\hline \multicolumn{3}{|c|}{ Subtotal } & 0.7477 & 11 & 2.32 \\
\hline No & Code & Weakness(W) & Weight & Rating & Score \\
\hline 1 & W1 & TOGA price is low & 0.0872 & 4 & 0.3487 \\
\hline 2 & W2 & Lack of orders/requests & 0.0509 & 3 & 0.1527 \\
\hline 3 & W3 & Poorly developed relations & 0.0464 & 3 & 0.1393 \\
\hline 4 & W4 & There is no post-harvest processing & 0.0375 & 4 & 0.1502 \\
\hline 5 & W5 & Drugs from TOGA are less practical & 0.0302 & 3 & 0.0907 \\
\hline \multicolumn{3}{|c|}{ Subtotal } & 0.2523 & 17 & 0.8815 \\
\hline \multicolumn{3}{|c|}{ TOTAL } & 1 & 28 & 1.4384 \\
\hline
\end{tabular}

Source: Primary Data Processing, 2021.

Based on available data presented in Table 2, shows that the overall weight of the internal strength factor (strengths) is greater than $d$ with internal factors weakness (weakness). Likewise, the total score of the internal factors of strength is greater than that of 
the internal factors of weakness. In terms of strength, TOGA has multifunctionality, which is part of the factors that have the highest weight and score. Meanwhile, on the weak side, TOGA's price factor, which is still low in value, is also part of the weakness that deserves attention. The total score of internal factors obtained, namely the subtotal score of strengths minus the subtotal score of weaknesses, resulted in a positive score of 1.4384 .

Table 3 - EFAS Calculation of Strategy for Women's Empowerment around the Martapura River Basin in Utilizing Yard Land for TOGA Farming

\begin{tabular}{|l|l|l|l|l|l|}
\hline \multicolumn{2}{|l|}{ EXTERNAL FACTORS } \\
\hline No & Code & Opportunity(O) & Weight & Rating & Score \\
\hline 1 & O1 & Community needs for daily needs & 0.3187 & 4 & 1.2746 \\
\hline 2 & O2 & Healthy lifestyle & 0.1222 & 3 & 0.3665 \\
\hline 3 & O3 & Opening business/work opportunities & 0.0839 & 3 & 0.2517 \\
\hline Subtotal & Code & Threat(T) & 0.5247 & 10 & 1.8928 \\
\hline No & Cxistence of generic/chemical drugs & Weight & Rating & Score \\
\hline 1 & T1 & Exing & 0.2204 & 4 & 0.8816 \\
\hline 2 & T2 & Lack of interest in TOGA & 0.128 & 3 & 0.3841 \\
\hline 3 & T3 & Possible Flood & 0.1269 & 3 & 0.3806 \\
\hline Subtotal & & 0.4753 & 10 & 1.6463 \\
\hline TOTAL
\end{tabular}

Source: Primary Data Processing, 2021.

Based on the data presented in Table 3, shows that the overall weight of the external factors of opportunities (opportunities) is greater than the external factors of threats (threats). Likewise, the total score of external factors has greater opportunities than external factors of weakness. In terms of opportunity, that TOGA is needed by the community for daily needs is part of the factor that has the highest weight and score. Meanwhile, on the threat side, the presence of generic/chemical drugs in the market is also a threat, having a relatively high weight and score compared to other threats. The total score of external factors obtained, namely the subtotal score from opportunities reduced by the subtotal score from threats, resulted in a positive value of 0.2465 .

Analysis diagram is obtained from the calculation of internal factors and external factors, namely the total score. Based on the total score above, it can be illustrated by a SWOT analysis diagram in Figure 1.

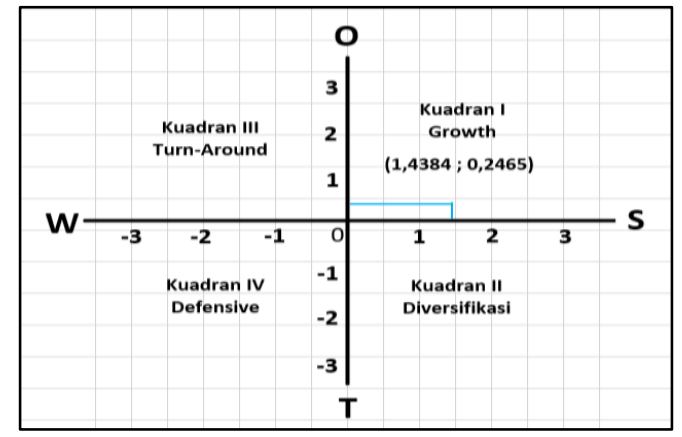

Figure 1 - SWOT analysis diagram of the Strategy for Empowering Women Around the Martapura Watershed (DAS) in the Utilization of Yard Land for TOGA Farming

Based on Figure 1, the SWOT analysis diagram shows that the Empowerment Strategy Women Surrounding the Martapura Watershed (DAS) in the Utilization of Yard Land for Farming TOGA is in quadrant I, which means a very favorable condition. The community has the power to take advantage of business opportunities. The strategy used in this condition is to support significant (Growth oriented strategy).

From the results of the questionnaire, the assessment of each alternative strategy by experts and related sector leaders, then processing with pairwise comparison matrices at the hierarchical level. Furthermore, the consistency test can be carried out on the assessment. If thevalue has been obtained Consistency Ratio or $<0.1$; the data obtained is consistent. 
Furthermore, theobtained geometric mean from each criterion. Thepairwise comparison matrix geometric meanof alternative strategies can be seen in Table 5.

Table 4 - SWOT Matrix Women Empowerment Strategies Around the Martapura Watershed (DAS) in Using Yard Land for Farming TOGA

\begin{tabular}{|c|c|c|}
\hline \multirow{6}{*}{ IFAS/EFAS } & Strengths (S) & Weaknesses (W) \\
\hline & TOGA is multifunctional (S1) The & price of TOGA is low (W1) \\
\hline & Seeds easy to obtain (S2) & Lack of orders/demands (W2) \\
\hline & Can be planted in a narrow area (S3) & Poorly developed relationships (W3) \\
\hline & As first aid medicine (S4) & No post-harvest processing (W4) \\
\hline & Reduce doctor fees (S5) & Medicines from TOGA less practical (W5) \\
\hline Opportunity (O) & SO & Strategy WO strategy \\
\hline $\begin{array}{l}\text { Community needed for } \\
\text { daily needs }(\mathrm{O} 1)\end{array}$ & Relying on product excellence & $\begin{array}{l}\text { Conducting partnership programs between } \\
\text { producers and marketing agencies }\end{array}$ \\
\hline Healthy lifestyle (O2) & \multirow{2}{*}{$\begin{array}{l}\text { Promoting socialization of the use of family } \\
\text { medicinal plant cultivation ( TOGA) through face- } \\
\text { to-face and social media }\end{array}$} & \multirow{2}{*}{$\begin{array}{l}\text { Developing products produced through } \\
\text { processing results }\end{array}$} \\
\hline $\begin{array}{l}\text { Opening business/work } \\
\text { opportunities (O3) }\end{array}$ & & \\
\hline Threats $(\mathrm{T})$ & ST & Strategy WT strategy \\
\hline $\begin{array}{l}\text { Existence } \\
\text { generic/chemical drugs } \\
\text { (T1) }\end{array}$ & $\begin{array}{l}\text { Promotion of extensions to family medicinal plant } \\
\text { business actors (TOGA) }\end{array}$ & \multirow{3}{*}{$\begin{array}{l}\text { of a medicinal plant market by relevant } \\
\text { agencies }\end{array}$} \\
\hline $\begin{array}{l}\text { Lack of interest in TOGA } \\
\text { (T2) }\end{array}$ & \multirow{2}{*}{$\begin{array}{l}\text { EstablishmentHolding seminars/ business } \\
\text { promotions regarding the benefits of using family } \\
\text { medicinal plants (TOGA) }\end{array}$} & \\
\hline $\begin{array}{l}\text { Lack of government } \\
\text { support (T3) }\end{array}$ & & \\
\hline
\end{tabular}

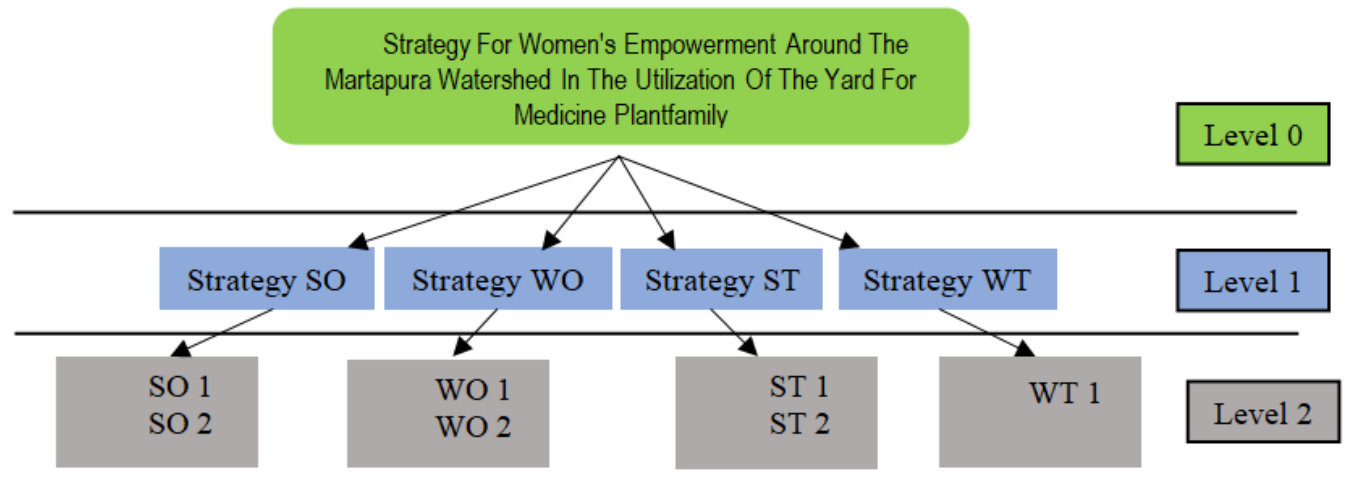

Figure 2 - Hierarchical Structure of Women's Empowerment Strategies Around the Martapura Watershed (DAS) in the Utilization of Yard Land for TOGA Farming

Table 5 - Pairwise comparison matrix of alternative strategies

\begin{tabular}{|l|l|l|l|l|l|l|l|}
\hline n/n & SO1 & SO2 & WO1 & WO2 & ST1 & ST2 \\
\hline SO1 & 1,0000 & 2,0000 & 0,3333 & 0,2500 & 3,0000 & 4,0000 \\
\hline SO2 & 0,5000 & 1,0000 & 0,2000 & 0,1667 & 2,0000 & 3,0000 \\
\hline WO1 & 3,0000 & 5,0000 & 1,0000 & 0,5000 & 6,0000 & 7,0000 & 2,0000 \\
\hline WO2 & 4,0000 & 6,0000 & 2,0000 & 1,0000 & 7,0000 & 8,0000 & 6,00000 \\
\hline ST1 & 0,3333 & 0,5000 & 0,1667 & 0,1429 & 1,0000 & 2,0000 & 0,5000 \\
\hline ST2 & 0,2500 & 0,3333 & 0,1429 & 0,1250 & 0,5000 & 1,0000 \\
\hline WT1 & 0,5000 & 0,5000 & 0,2000 & 0,1667 & 2,0000 & 3,0000 & 1,0000 \\
\hline Amount & 9,5833 & 15,3333 & 4,0429 & 2,3512 & 21,5000 & 28,0000 \\
\hline
\end{tabular}

Source: Primary Data Processing, 2021.

Next is looking for an alternative criterion or strategy to be priority of the members of the SWOT analysis factors that have been identified through the AHP normalization process. As well as a consistency test on the criteria assessment, if the results obtained are inconsistent then the data collection must be repeated. The results of the calculation of strategic priorities and consistency tests can be seen in Table 6 below.

AHP calculation end result is a strategy that should be prioritized in the empowerment of women around Watershed Martapura River (DAS) in the Utilization of Yard Land for 
Business ani Family Medicinal Plants (TOGA). From the calculation of the priority of alternative strategies, it can be seen in the form of a pie chart in Figure 2.

Table 6 - Priority Calculation Results and Consistency Test

\begin{tabular}{|c|c|c|c|c|c|c|c|c|c|c|}
\hline$n / n$ & SO1 & SO2 & WO1 & WO2 & ST1 & ST2 & WT1 & Jumlah & $\begin{array}{l}\text { Priority } \\
\text { Vector }\end{array}$ & $\begin{array}{c}\text { Matrix } \times \\
\text { Priority Vector }\end{array}$ \\
\hline SO1 & 0,1043 & 0,1304 & 0,0824 & 0,1063 & 0,1395 & 0,1429 & 0,1188 & 0,8248 & 0,1178 & 1,12914334 \\
\hline SO2 & 0,0522 & 0,0652 & 0,0495 & 0,0709 & 0,0930 & 0,1071 & 0,1188 & 0,5567 & 0,0795 & 1,2194936 \\
\hline WO1 & 0,3130 & 0,3261 & 0,2473 & 0,2127 & 0,2791 & 0,2500 & 0,2970 & 1,9252 & 0,2750 & 1,11192315 \\
\hline WO2 & 0,4174 & 0,3913 & 0,4947 & 0,4253 & 0,3256 & 0,2857 & 0,3564 & 2,6964 & 0,3852 & 0,90569304 \\
\hline ST1 & 0,0348 & 0,0326 & 0,0412 & 0,0608 & 0,0465 & 0,0714 & 0,0297 & 0,3170 & 0,0453 & 0,97370102 \\
\hline ST2 & 0,0261 & 0,0217 & 0,0353 & 0,0532 & 0,0233 & 0,0357 & 0,0198 & 0,2151 & 0,0307 & 0,86039365 \\
\hline WT1 & 0,0522 & 0,0326 & 0,0495 & 0,0709 & 0,0930 & 0,1071 & 0,0594 & 0,4647 & 0,0664 & 1,11751859 \\
\hline Jumlah & 1 & 1 & 1 & 1 & 1 & 1 & 1 & 7 & 1 & 7,31787 \\
\hline \multicolumn{2}{|c|}{ Menghitung CR Kriteria } & \multirow{5}{*}{\multicolumn{9}{|c|}{$\leftarrow \mathrm{CR}$ value is less than $0.1(\mathrm{CR}<0.1)$ : Consistent conclusion }} \\
\hline$\lambda$ Maks & 7,3179 & & & & & & & & & \\
\hline $\mathrm{Cl}$ & 0,0530 & & & & & & & & & \\
\hline $\mathrm{RI}$ & 1,3200 & & & & & & & & & \\
\hline $\mathrm{CR}$ & 0,0401 & & & & & & & & & \\
\hline
\end{tabular}

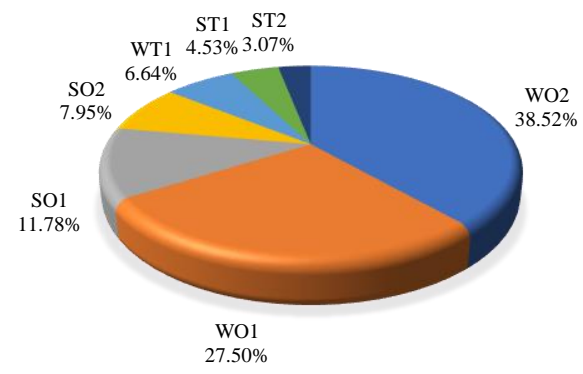

Figure 2 - Diagram Pie Chart Strategy Priority

Based on the order of strategic priorities that have been presented in Figure 5.11, it shows that the results of the questionnaire data processing using the AHP method are WO2: developing products produced through processing results $(38.52 \%)$, WO1: conducting partnership programs between producers and marketing agencies (27.50\%), SO1: relying on product superiority (11.78\%), SO2: promoting socialization of the use of family medicinal plant cultivation (TOGA) through face-to-face and social media (7.95\%), WT1: establishment of a medicinal plant market by the relevant agencies (6.64\%), ST1: re-encouragement of extensions to family medicinal plant business actors (TOGA) (4.53\%), and ST2: holding seminars/business promotions regarding the benefits use of family medicinal plants (TOGA) (7.56\%).

\section{CONCLUSION}

The conclusions and suggestions from the results and discussion of this study are:

- The total score of internal factors obtained, namely the subtotal score of strengths minus the subtotal score of weaknesses, produces a positive value of 1.4384;

- The total score of external factors obtained, namely the subtotal score from opportunities reduced by the subtotal score from threats, resulted in a positive value of 0.2465 ;

- Strategy for Empowering Women Around the Martapura Watershed (DAS) in the Utilization of Yard Land for Farming TOGA is in quadrant I, which means a very favorable condition;

- SO Strategy (Relying on product superiority \& promoting socialization of the use of family medicinal plant cultivation (TOGA) through face-to-face and social media). WO Strategy (Doing a partnership program between producers and marketing agencies \& Developing products produced through processing the results). ST Strategy (Reinforced extensions to family medicinal plant business actors \& Holding 
seminars/business promotions regarding the benefits of using family medicinal plants). WT Strategy (The establishment of a medicinal plant market by the relevant agencies);

- The priority strategies based on the results of the questionnaire data processing using the AHP method are WO2: developing products produced through processing results (38.52\%), WO1: conducting partnership programs between producers and marketing agencies (27.50\%), SO1: relying on product advantages (11.78\%), SO2: promoting socialization of the use of family medicinal plant cultivation (TOGA) through face-to-face and social media $(7.95 \%)$, WT1: establishment of a medicinal plant market by the relevant agencies $(6.64 \%)$, ST1 : re-encouragement of extensions to business actors of family medicinal plants (TOGA) (4.53\%), and ST2 : holding seminars/business promotions regarding the benefits of using family medicinal plants (TOGA) $(7.56 \%)$.

\section{ACKNOWLEDGMENTS}

Researchers would like to thank the Institute for Research and Community Service (LPPM) of Lambung Mangkurat University which has funded research through DIPA Lambung Mangkurat University for Fiscal Year 2021 based on contract number 008.37/UN8.2/PL/2021.

\section{REFERENCES}

1. Ministry of Health RI. Utilization of Medicinal Plants. Jakarta 1992.

2. Harini S, Suyono, Mutiara E, 2012. Community-Based Management of Critical Land Processing in the Upper Brantas Watershed (Pilot Project in Bulu Kerto Village, Batu City.

3. Hastuti and Respati, Dyah. 2009. Model for Empowering Poor Women Based on Utilization of Rural Resources Efforts Poverty Alleviation in Rural Areas, Yogyakarta State University.

4. Kuncoro \& Kadar, 2016. The Influence of Women's Empowerment and Improving Family Economic Resources, Journal of Buana Gender (Vol 1, Number 1), Surakarta.

5. Marimin, 2004. Techniques and Applications for Decision Making with Multiple Criteria, Jakarta (ID): PT Gramedia Widiasarana Indonesia.

6. Marimin, Maghfiroh N. 2010. Application of Decision Making Techniques in Management. Bogor (ID): IPB Press.

7. Nurdiwaty, D., Puspita, E., Kusumaningtyas, D., Winarko, SP, Tohari, A., Solikhah, M., Faisol. 2017. Empowering Women through TOGA Plants to Help Increase Family Income. ABDINUS Journal, 1

8. Nuryanti, S., \& Swastika, DKS 2011. The Role of Farmer Groups in the Application of Agricultural Technology. Agro-Economic Research Forum, 29.

9. Saptatiningsih, RI 2015. Empowering Village Women to Reduce Poverty. Proceedings of the National Seminar of PGRI Yogyakarta University. Yogyakarta.

10. Singarimbun and effendi, 1989. Survey Research Methods, LPES: Jakarta.

11. Siramba J. 2013. Community and Perceptions of the Community Forest Development Plan (Hkm) in Leboni Village in the Sintuwu Maroso KPHP Model, Poso Regency. Essay. Faculty of Forestry, Tadulako University.

12. Suganda E, Yatmo YA, and Atmodiwirjo P, (2009). Environmental management and community conditions In the downstream area of the river.

13. Tukiman. 2004. Utilization of Family Medicinal Plants (TOGA) for Family Health. Section of Health Education and Behavioral Sciences, Faculty of Public Health, University of North Sumatra. USU: Digital Library.

14. Widjajanti K. 2011. Community Empowerment Model. Journal of Development Economics Volume 12, Number 1, June 2011. 